RESEARCH PAPER

\title{
Challenges of Social Sector Development in Balochistan during Musharraf Era (1999-2008)
}

\section{Dr. Saima Butt* $\quad$ 2Dr. Kalsoom Hanif}

1. Assistant Professor, Department of Political Science, Lahore Collage for Women University, Lahore, Punjab, Pakistan

2. Assistant Professor, Department of History Department, Lahore Collage for Women University, Lahore, Punjab, Pakistan

\begin{tabular}{|c|c|}
\hline PAPI & \\
\hline $\begin{array}{l}\text { d: } \\
021 \\
021\end{array}$ & $\begin{array}{l}\text { Balochistan being richest in natural resources unfortunately reflects a } \\
\text { low percentage of development in all social sector indicators. The } \\
\text { social sector is a backbone of any society, development in this sector } \\
\text { ensures development in all other sectors of society. Education, health, }\end{array}$ \\
\hline $\begin{array}{l}\text { eywords: } \\
\text { iteracy Ratio, } \\
\text { IDI, } \\
\text { ocial Sector, } \\
\text { aw and Order, } \\
\text { uman } \\
\text { ights }\end{array}$ & $\begin{array}{l}\text { drinking water and, law and order situation in Balochistan has been } \\
\text { alarming since August } 1947 \text { and it continued to haunt government of } \\
\text { Pakistan after independence. Social sector of Balochistan neglected by } \\
\text { government of Pakistan and Balochistan since its annexation with }\end{array}$ \\
\hline $\begin{array}{l}\text { *Corresponding } \\
\text { Author: }\end{array}$ & $\begin{array}{l}\text { Pakistan. This piece of work highlights the impact of the social sector } \\
\text { policies of Pervez Musharraf and its impact on the local politics and } \\
\text { society, especially highlighting the grievances of the Baloch during this } \\
\text { period. }\end{array}$ \\
\hline
\end{tabular}

Introduction

Pakistan since its inception faced multiple challenges in the social-economic and political sector. Balochistan is territorially the largest of the four provinces of Pakistan having a total area of 347,188 Square Kilometers. According to the 1998 population census Balochistan is home to 6,511,000 inhabitants. However, the province of Balochistan which roughly consists of $45 \%$ of the total territory of Pakistan specifically lacked behind in the social-economic and political sector compared with other three provinces of Pakistan. Education brings awareness, but Balochistan still has one of the lowest literacy rates in Pakistan. Challenges in health sector in Balochistan are lack of infrastructure and commitment of government to provide it. Balochistan stands last in HDI when compared with Punjab, Sindh and, KPK. Balochistan is known for its gas reserves, but its consumption in Balochistan is also lowest comparing with other provinces. Agriculture is not the strong sector of the province due to scarcity of water yet the capacity of the province still not fully explored due to infrastructure limitations. Law and order is the prior condition for 
advancement in any sector, sadly it's a big challenge for provincial and federal government to ensure it. Prolong insurgencies left the deep imprints on the Baloch society as it developed arms culture, IDPs and missing person issues is yet another challenge for the state. The focus of this study has however been limited to the events and developments related to Balochistan, as unfolding during the era of Pervez Musharraf, who ruled Pakistan, from $12^{\text {th }}$ of October 1999 when he took-over Pakistan, as its Chief Executive, after toppling and deposing the then elected Prime-Minister Nawaz Sharif.

\section{Social Sector Development in Balochistan}

One of the most significant measures of socio-economic development of a nation is its literacy rate and the quality of education that it imparts to its youth. Formal education institutions were established in Balochistan much later than rest of sub-continent, other than that Baloch people had not even the traditional educational lines. Baloch society had Mullah or Syed to serve the religious function. This type of education was only restricted to the traditional methods. These education institutions were not imparting modern knowledge and scientific education. The advent of British along with different administrative systems competed to the local people to equip themselves with the modern education (Rizvi, 2008). The first ever Anglo-Vernacular school for boys opened in Quetta in 1881, the Khan of Kalat was the first local person who opened a school in 1904 at Mastung. There was no separate setup of education department in Balochistan before 1920.The link between education and awareness was clear on British part so they put no serious effort to educate the Baloch masses to avoid the political consciousness among the people. There were only three public libraries in Muslim majority areas of the whole subcontinent (Syed, 2008).

Unfortunately, Pakistan, right from its independence, has been overwhelmed by its immediate security concerns, due to the presence of a hegemonic and hostile neighbor on its eastern frontiers in the shape of India. Even after 65 years of independence, we have not been able to find a way of peaceful co-existence with India. As a result, our security concerns are even greater today, and Pakistan is constrained to run a mad race of armspurchasing and defense spending with India, while the amount allocated on vital socioeconomic development indicators like education and literacy is still abysmal. Even amongst the four federating units, the position is worse for less developed provinces. For example, the official figures of literacy ratio in Balochistan are 29.81 percent. This percentage was further divided among male and female. The literacy ratio in male and in female (rural) is given in the figure below (Sial \& Basit, 2010)

\section{Literacy Ratio}

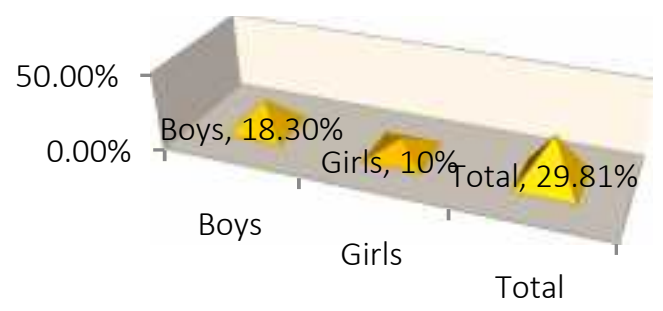


Lowest primary enrolment of 11 out of 16 districts of Balochistan was recorded in the year 2004-05. There are four public sector universities, five for boys and only one university for women in Balochistan. There is only one vocational institute for women in contrast with Punjab where 111 vocational institutions are working. Only 23\% of girls from rural area are fortunate to be enrolled in primary schools. The report of 2004 of Balochistan government showed over all ratio of literacy in Pakistan given in figure below (Govt. of Balochistan, 2004)

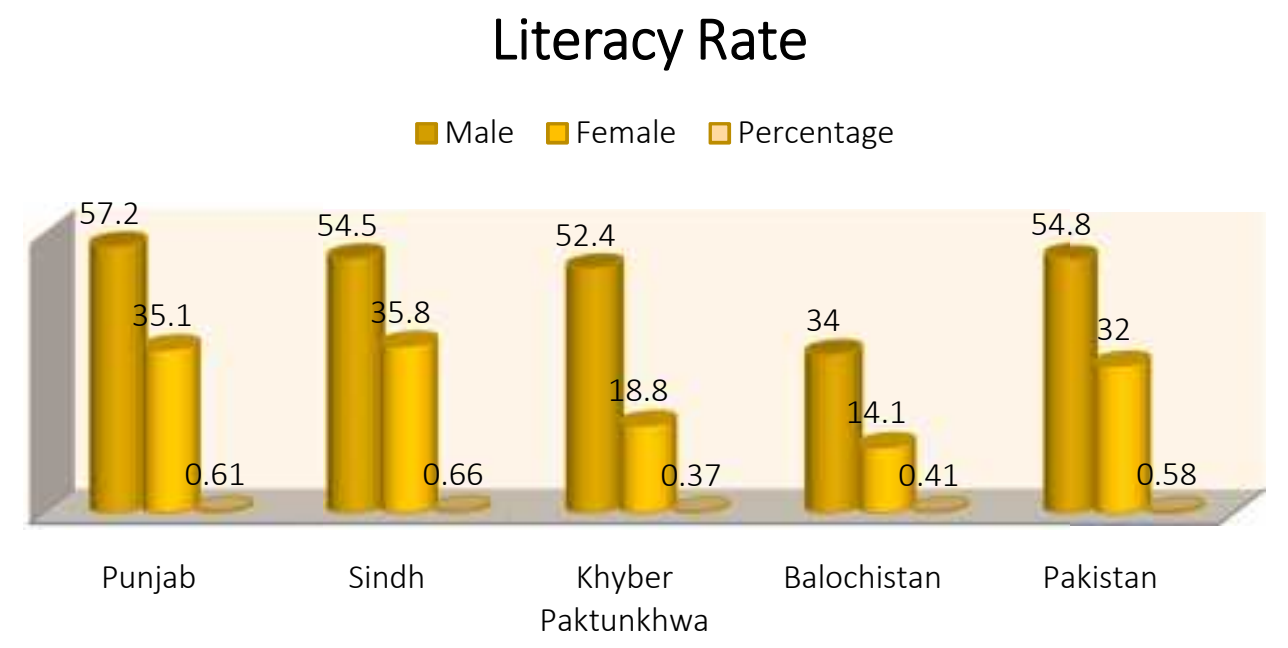

Balochistan is the province which is ranked at last in Pakistan in terms of Human Development Index (HDI). The United Nations reported the resource rich 'Dera Bugti' ranked at 0.285 in HDI in contrast with the district Jhelum (Punjab) which ranked at 0.703 in respect of HDI. The difference is shown in the figure below (Jetly, 2009).

\section{HDI of 2003}

\section{Percentage at HDI}

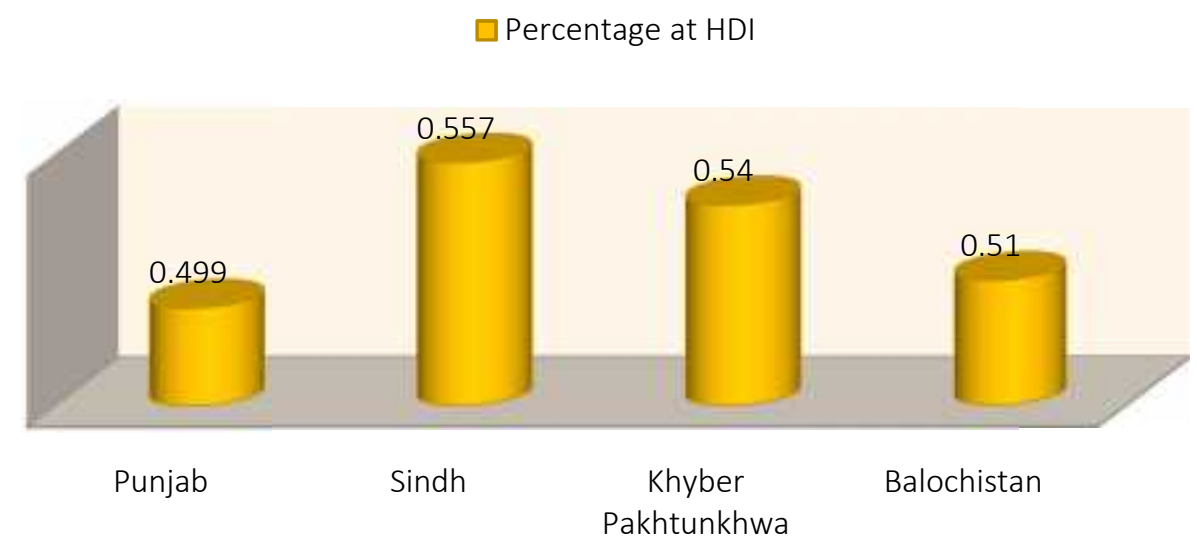


Sial and Basit (2010) quotes Vice Chancellor of Balochistan University, Professor Abdul Nabi , "one of the serious concerns of Baloch youth was that they did not have enough education institutions, neither teachers and if they were able to get education then job opportunities were fewer for them."(p.17). This situation might push youth towards violent activities. Long-lasting deprivation and despondency push people towards the use of unfair means for survival. Such extra-ordinary means may include resorting to militant or anti-state activities. That is how the Balochistan Students Organization (BSO) came into force. This was initially a student organization, which later broadened its charter of demands and scope of work. Central government's relationship with Balochistan government is not a democratic relation-ship but is instead a Patron-client arrangement. The provincial government of Balochistan has almost no authority to appoint its high officials; sixty percent of the seats are filled through the federal government nominations. Chief Justice of High Court and Chief Secretary are appointed by the central government. Inspector General of Frontier Corps (FC) directly takes orders from the center, in stark contrast to the constitution which declares 'law and order' to be a provincial subject. Baloch are seen nowhere on the national scene. In the 200 corporations operating in Pakistan, there is not a single Baloch. There is not a single Baloch ambassador of Pakistan in any country. Balochistan has only 16 National Assembly seats in the Parliament, out of the total 342, which depicts the extent of under-representation of Balochistan in the lawmaking process at the national level (Sial \& Basit, 2010).

Only $25 \%$ of the Baloch population has access to electricity in comparison with the $75 \%$ of the total population of Pakistan. The "high deprivation" rate in the province is shown in figure below (Baloch, 2007).

\section{Ratio of High Deprivation in the Provinces}

\section{$\%$ of high deprivation}

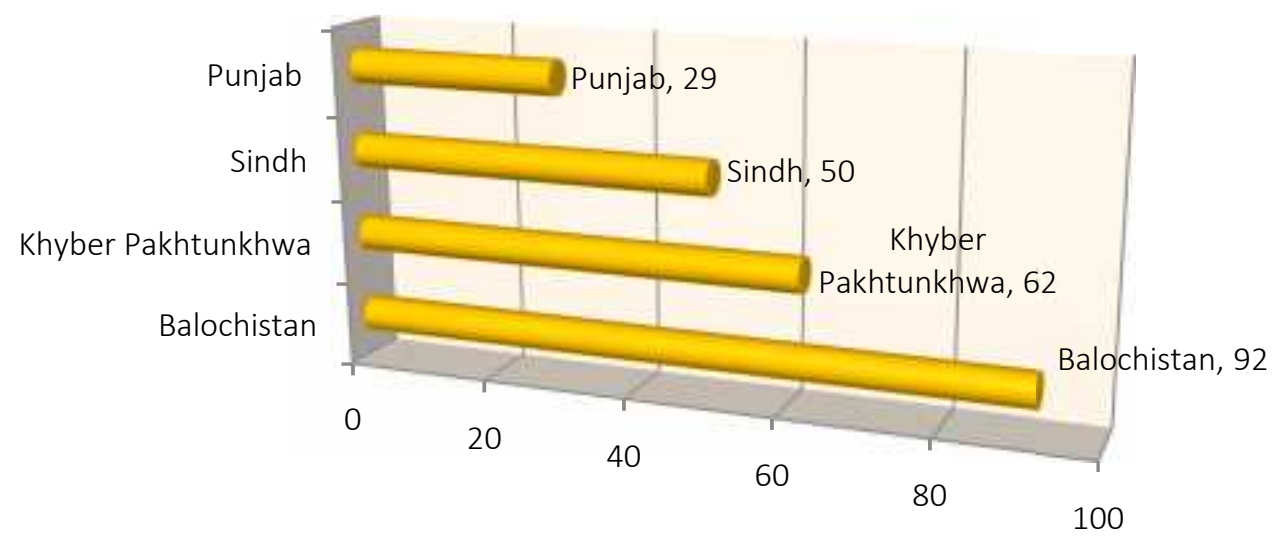

Gas consumption in Balochistan province is just 3.4\% as compared with Punjab which alone consumes $51 \%$ of the total gas production. Balochistan's contribution to the national revenue is 85 billion rupees but it only receives $7 \%$ of that in return. In Balochistan alone 63\% population is living below the poverty line (Baloch, 2007). One of the long standing issue of Baloch's has been that their job quota in the Pakistan army was not raised, as a result of which they were seriously under-represented in army. It is 
however encouraging noting that there is slight improvement since 2001 when the Baloch's quota in army was raised from 2 to 4 percent (PILDAT, 2012).

Ex-President Musharraf showed his commitment to uplift the province. To fulfill his commitment, he paid out about Rs 495 percent amount in different departments of Balochistan. The resource allocation in different departments of the Balochistan from 2005 to 2007 is as shown in the figure below (Salman,Raashid, 2008).

Resource Allocation in Balochistan 2005-07

\section{Resources}

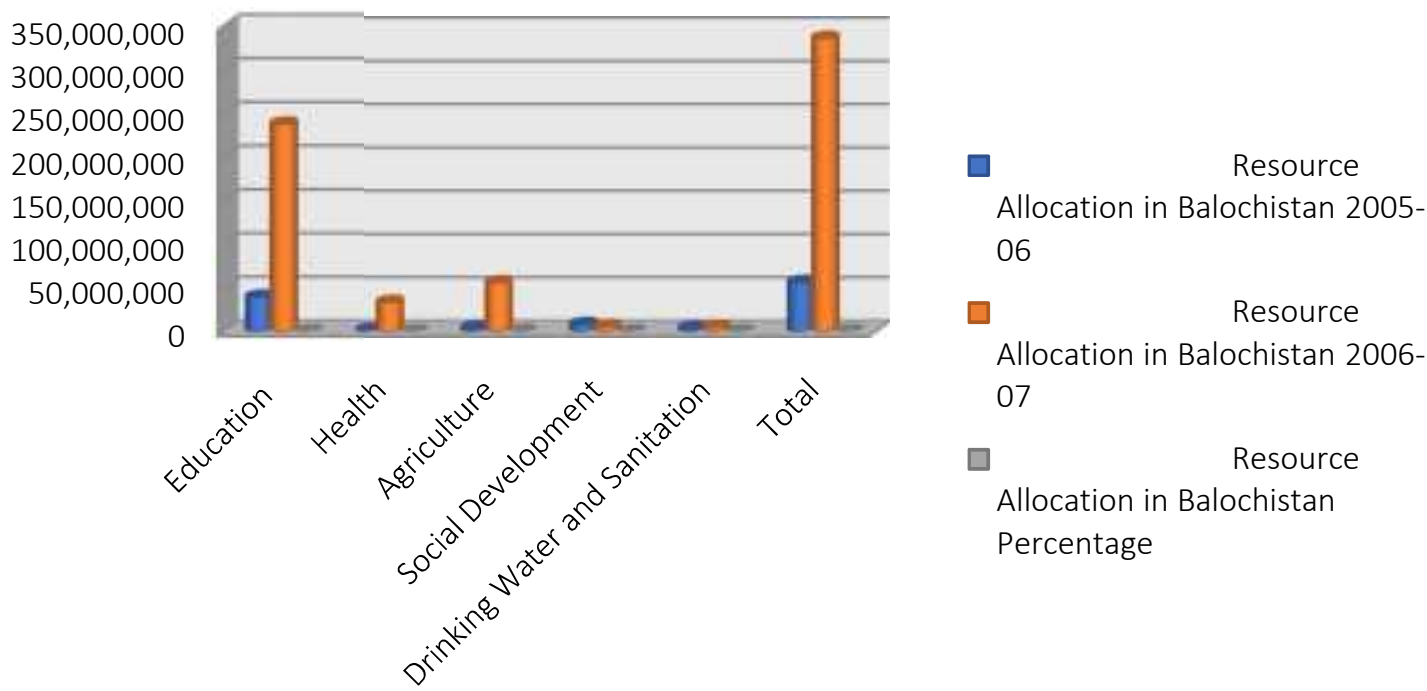

As shown in figure above maximum amount was allocated to the education sector, which has traditionally been a neglected sector. Agriculture and Health got better treatment too, as they got increased allocations for development.

\section{Law Enforcement Agencies}

Balochistan is territorially a large province. Administratively it has been divided into 30 districts, which have been further marked as " $\mathrm{A}$ " and " $\mathrm{B}$ " category districts, for more focused law and order control policies. The town and cities falling under " $A$ " category are those that are looked after by regular police force. There are 89 police stations under category "A". Category "B" areas are those that are under 'Levies' control; there are 286 thanas under the Levies. Levies are recruited not on merit, but on the nomination of the concerned tribal leaders. More than 95\% area of Balochistan comes under category "B". Law and order situation is generally much better in " $\mathrm{A}$ " category areas then the " $\mathrm{B}$ " areas. The government plans to merge " $\mathrm{B}$ " category into " $\mathrm{A}$ " to improve law and order situation. However, such proposals were vehemently opposed by the administration of "B" category for the fear that it would render thousands of locals jobless. However, a comparison of multiple crimes conducted in the areas 'A' and 'B' between the year 2002-03 are given in figure below (Senate of Pakistan, 2005). 


\section{Heinous Crimes from 2002-2003}

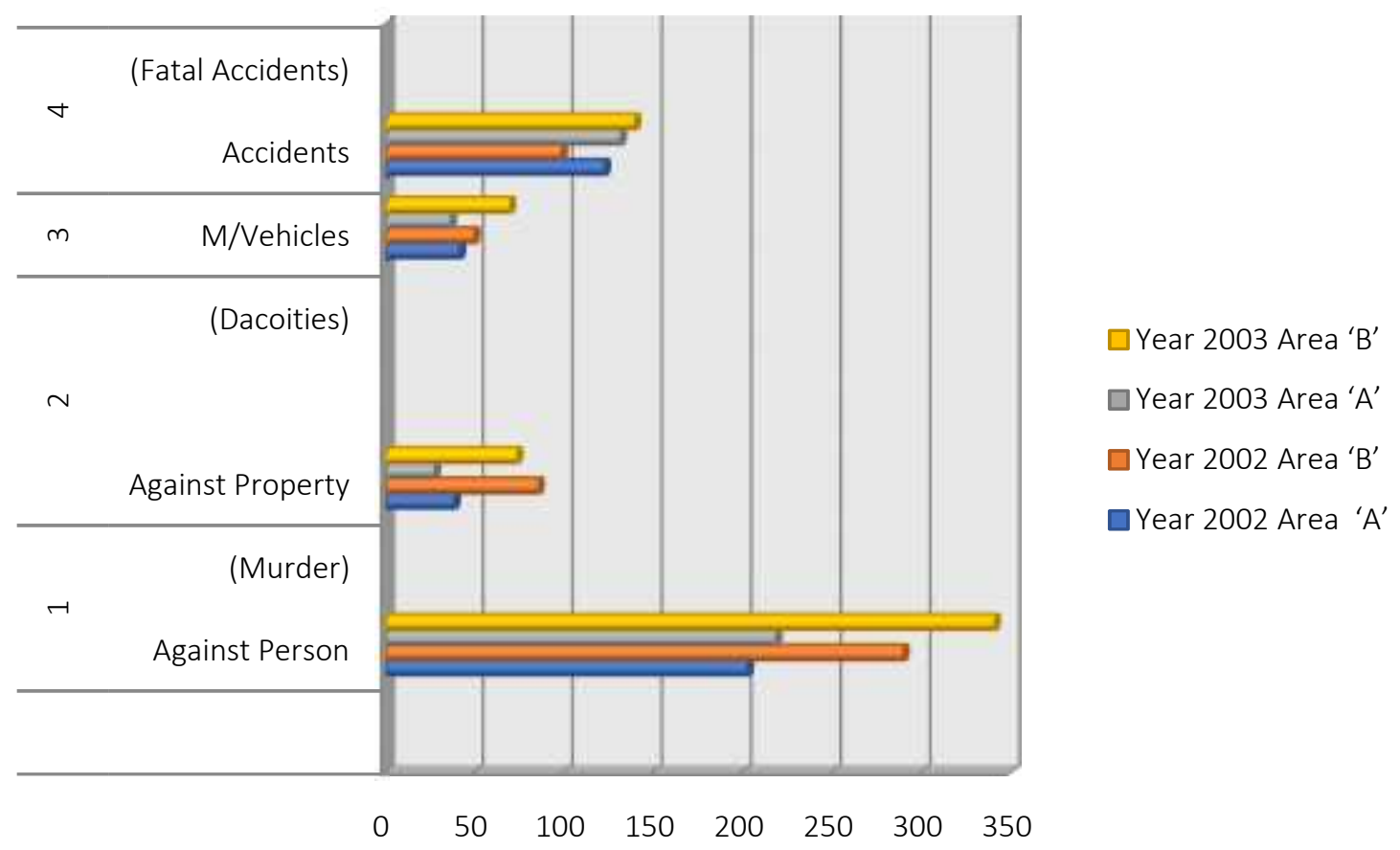

Other then the petty crimes carried out in the areas ' $\mathrm{A}$ ' and ' $\mathrm{B}$ ' there were an added terrorist activity going on in these areas i-e destruction through the rocket fired, between the year 2002 to 2004 as shown in the figure (Senate of Pakistan, 2005)

\section{Rocket Fired in Area 'A' and 'B'}

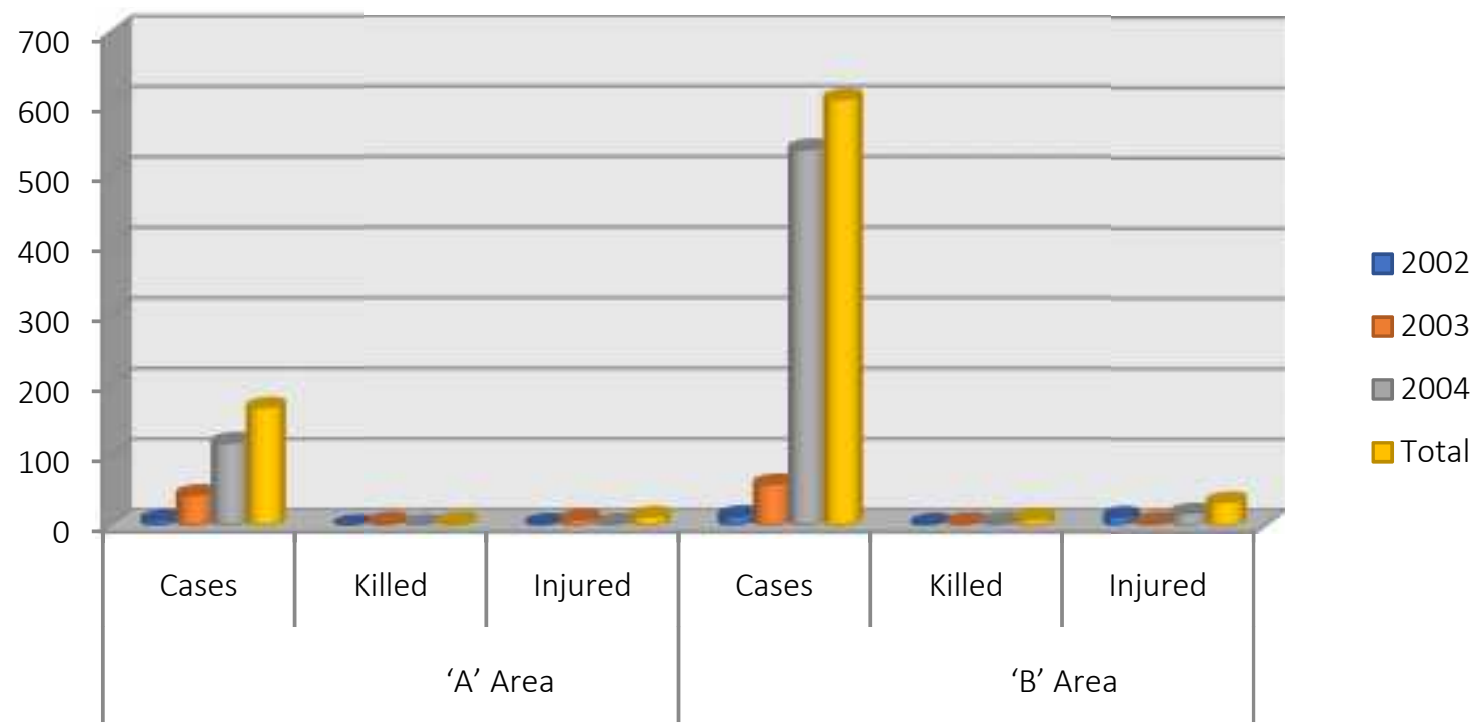


There is another law enforcing body currently working in Balochistan called Frontier Corps (FC). FC is a paramilitary agency constituted to control smuggling, drug trafficking and for maintaining law \& order situation in the province. Inspector General FC reports to the Federal Interior Ministry. Provincial Home Department requests the Federal Interior Ministry to assist the provincial government in controlling the law-and-order situation. The federal government of Pakistan over looks to consult the provincial government while deciding their affairs and imposed decision on them. The FC plays extensive role in the province. It has established 493 check posts in the area. There are frequent complaints by the locals against the alleged maltreatment and rude behavior of FC people with lay men at these check-posts. FC worked under the Frontier Corps ordinance 1959 which gives them authority to deal with external aggressor or with hostile tribes or other individuals helping them in their activities (Kundi, 1994).

There is another agency which monitors Balochistan's coastal belt, called Pakistan 'Coast Guards'. This force was established under 1973 Coast Guard Act; Coast Guards have established 87 check post to discharge their duties.

\section{Private Armies}

In Pakistan, the arms culture strengthened its roots with the Afghan war 1979. Balochistan is the province which not only got refugees from Afghan war but also an abundant supply of illegal arms. Arms culture in Balochistan did not start with Afghan war; it had been there for long as an arm carrying is the matter of prestige for the tribal people. All tribal sardars and the nawabs carry their personal guards and few of them also maintain their private military/militia, which is in stark violation of Article 256 of the 1973 constitution. It is reported that Marri tribe have 30,000 men strong armed force, while Bugti tribe too maintains its own armed force, almost equal in numbers to that of the Marri's. According to official reports, Akbar Bugti was running 60-62 militant training camps in Balochistan. Balach Marri, the son of Nawab Khair Bakhsh Marri, running numbers of 'Farari (Renegade) camps. Bugti \& Marri tribes are also accused with providing safe heavens to the run-away criminals of Sindh and Punjab Provinces. It is believed that these militant camps were mainly responsible of conducting anti-state sabotage activities in the province, wherein 20 law enforcement officials were killed while 53 were injured (in Bugti's area alone). There were 15 reported incidents where gas pipe lines were blown up, while 73 firing and 86 rocket launching attacks in Kohlu were reported during 2003-05. There are further complaints regarding illegal detention of people by Balach Marri in the "no go areas" which are inaccessible for the laymen (HRCP, 2006). Land mines were laid down by the insurgents in their areas which blasted when a lay man unknowingly stepped on it. This was a brutal technique by insurgents to kill the forces. Baloch were trained to launch the rocket launcher and with highly sophisticated guns (Raman, 2004). Holding private armies and guards, showed the level of distrust of the tribal people over the authorities. Federal authorities neither tried to change the tribal culture through a proper planning nor tried to engage these areas into mainstream politics of Pakistan. Central governments were always content dealing with the sardars and over looked the muchneeded changes the existing tribal setup. The tribal leaders were thus allowed to run a state within state, under their own rules, their own enforcement mechanism and a judicature of their own to punish the 'transgressors'. 


\section{Inter-Tribal Conflicts}

Another major issue in the Baloch tribal society that is that of inter-tribal conflict. HRCP team was approached by Sardar Ghulam Qadir Mansoori (sardar of sub-tribe of Bugti). Mansoori introduced himself as a member of the 'Majlis-e-Shoora' during Zia's regime. He claimed that he competed in election against Bugti son Salim Bugti, he lost the seat but secured good number of votes which annoyed Bugti. To teach him lesson he was picked up by Bugti and arrested at Bugti's jail. Mansoori escaped in 2005 from Bugti's jail but had been badly tortured. He, along with his tribe, were humiliated by Bugti. Mansoori demanded fair trail of this issue. On the contrary there is another view that Mansoori was backed by authorities. There was another group from Kalpars who met the HRCP team and disclosed their grievances. The group reported the same kind of insulting treatment by Bugti, who shaved their heads, beared and moustaches. The group claimed that area of Sui actually belonged to them and not to Bugtis. The rivalry between Kalpars and Bugtis started in 1992. Amir Hamza son of the Kalpar's Sardar was killed by the Salim Bugti son of Akbar Bugti. Amir was contested elections against Salal Bugti. However, only after a few days Salal was assassinated in Quetta. This was the situation reported by the statements of both tribes. No matter what the truth was but the fact is two persons were killed. The government must enforce the writ of the state by free and fair judicial process so that people start trusting the state authorities. The state jurisdiction must be extended to these tribal areas of the state so that no one dares to take law into his own hands (Muzaffar, et. al. 2018) (HRCP, 2006).

\section{Drugs and Weapons Smuggling}

Bringing of foreign origin goods into the country or taking the indigenous goods to a foreign country, without payment of statutory duty/taxes and other levies, or otherwise in contravention of the prevailing import/export restrictions imposed by Pakistani Law, is called the act of smuggling. Pakistan has long been a victim of smuggling. The smuggled goods of different categories reach Pakistani markets through Afghan and Iranian borders. Pakistan shares long mountainous border with Afghanistan and it is difficult for both countries to thoroughly check the border activities. The trend of smuggling (especially of the weapons) was the gift of Afghan war 1979. These activities were conducted by Afghan refugees who settled along the Quetta Chaman Highway. This area became the safe-haven car lifters, highway robbers, land-grabbers and drugs mafia. This area became known internationally South Asia golden triangle for smuggling. Besides the drug smuggling another gift of Afghan war were weapons and these weapons were more common in the province of Balochistan. Large number of illicit weapons is present in the provinces of which no record is available with authorities. The central government believed that insurgents are using these smuggled weapons. Central government is true in its claim; the highly sophisticated weapons are used by insurgents. The IEDs are used by insurgents and caused heavy damages (Sial \& Basit, 2010).

\section{Human Rights Violations in Balochistan}

\section{Disappearances of Local Persons}

Selig S Harrison US commentator and scholar on Asian affairs declared act of Pakistan army in the province as a "slow motion genocide" (Synnott, 2009). The term genocide indicates the deliberate killing of an ethnic group. Slow motion genocide refers to 
the killing of Baloch ethnic group in different time slots. This term was used in the context of Baloch community who was the target of central government since 1947. Soon after independence an operation was launched against Baloch leaders which ended with the arrest of noteworthy leader i.e. Prince Karim, along his companions. This was not the only example, but all four insurgencies ended with the same fate. The insurgency of 1973-75 was the bloodiest one. The fourth insurgency in which no exact figure of the dead and displaced has ever been made available (media did not have access to the troubled areas). Target of all four insurgencies were Baloch and Brahui's. These insurgencies left thousands of Baloch dead. The Baloch community is just 3.5\% of the total population of Pakistan and thickly inhabited in Balochistan. Baloch community is already struggling for their survival against local Pashtuns, who were leading in business and were well-off economically in comparison. There was alarming increase in the number of Pashtun refugees during 1979 Afghan war. The Afghan refugees were given Pakistani nationality and now they were qualified to cast vote. This large influx of Pashtun immigrants changed the demography of the Balochistan forever.

Military not only launched operation against rebels but also took action against their families. Baloch from all walks of life were picked up by military, without any procedure of law, for investigation purpose. Most of them were never to be seen again, and those found at all, were in the shape of mutilated corpses. The missing persons belong to all fields such as doctors, teachers, lawyers, political workers and even laymen. These persons were picked up, ostensibly, because they were supporting the cause of the 'rebels' in some way. According to HRCP report, by the end of 2006, there were 242 cases of missing people on HRCP list, out of which 170 hailed from Balochistan. The figure was a rough estimate as there was no access to the missing person's families. The missing person's families were threatened by agencies against registration of cases with police, so the actual number of missing persons is not on record. HRCP filed a petition for the missing persons before the Supreme Court of Pakistan in March 2007. There were 148 verified missing persons on HRCP list. The government answered the Supreme Court that 113 out of 254 persons had been traced and government tried to locate the rest. HRCP demanded that government should submit affidavits, as to how many people had actually been recovered as all the government statement were verbal and no written documents were submitted. The Supreme Court ordered the government officials to summit the affidavit about the location of these persons and charge-sheets filed against them, if any. Supreme Court also instructed government to clarify the position of disappeared persons i.e. either they had been released or otherwise presented before court.

The Chief Justice of Pakistan Iftikhar Mohammad Chaudhry said that the Court had proofs that intelligence agencies were involved in the illegal detention of the missing people. The court ordered that if Director General of Federal Intelligence Agency was not able to produce the missing person he may be arrested. After court's stern orders, two missing person were released. Iftikhar Mohammad Chaudhry visited Balochistan and asked provincial government officials to submit report as to why intelligence agencies had picked political workers, as it was sheer violation of the constitutional rights of the citizens. Munir Mengal the director of Baloch television was arrested by agencies in 2006 and was released only in 2007 on court orders. According to his family he again disappeared and his family is unable to locate his position (ICG, 2007). 
The actual figure of misplaced people is not known. The Baloch nationalist said it is from 8,000 to 12,000 . The other figure is given by interior minister is of 5000 , however these figures were never confirmed as no independent source was allowed to visit affected areas. Musharraf once said that these missing persons went for jihad in Kashmir or Afghanistan. ICG (2007) quotes BSO activist "The Baloch are not and have never been jihadis" (p.5).The Afghan war was fought by Pashtuns of Balochistan. The Madrissas were established in Pashtun areas and the recruitment was among Pashtun class. Baloch are historically more secular in nature. Their tribal identity precedes their religious identity.

\section{Missing Persons Cases}

Ali Asghar Bangulzai Baloch was picked up by the intelligence agencies from his tailoring shop. He was accused with the murder of Justice Nawaz Marri (that took place on in June $1^{\text {st }}, 2000$ ). Ali was released after 14 days, but was picked up once again on 18 October 2000. In 2002 his family contacted Corps Commander Abdul Qadir Zari for ending Ali's detention. The official responded that Ali was with ISI and he will be released soon. Getting no news of Ali his family met Governor of Balochistan and HRCP Vice Chairperson of Balochistan was also present at the meeting. In the next meeting Governor informed Ali's family that he was not in the custody of any official agency. The family had doubts and said that ISI itself received clothes of Ali from his family and also gave 25,000 Rs to them. Ali was father of eight children. Outside Quetta press Club Ali's family observed token hunger strike. That was the gesture of helplessness and protest of the helpless people of Pakistan (HRCP, 2006).

\section{Inhuman Torture}

HRCP (2006) gives definition of torture according to UN reporter who visited Pakistan in 1997 "Torture, including rape, and similar cruel inhuman or degrading treatment are rife in Pakistan, although those with important family, political or international connections are somewhat less at risk of the most extreme forms of torture"(p.18).

The most common form of torture in Pakistan is under the custody of police, paramilitary forces and the armed forces. The constitution of Pakistan gives absolutely no authority to any public functionary, to detain or arrest any person, except in strict conformity with the procedure laid down under code of criminal procedure. The constitution, however, does not tell how to deal with the violators of the constitution. Article 14 of the constitution says that "the dignity of man shall be protected" the article second by sub article which said "No person shall be subject to torture for the purpose of extracting evidence" (p.10). Constitution ensures the protection of dignity and self-esteem of the citizens of Pakistan. The article however, needs some interpretation on the part of the enforcement agencies where constitution remains silent. The enforcement of laws and the punishment of the violators both are interrelated, if constitution is not able to clarify the punishment on the part of the violator, then the law is hard to follow. The United Nations Code of Conduct for law enforcement officials gives a comprehensive definition of torture and the measures to enforce it. The UN Article 5 of the code says that no official has the authority to opt any type of the torture under normal circumstances. The officials were also directed to not to violate act under the emergency situation, national security question, war or state of war and any other type of political instability situations. Government of Pakistan should sign the UN charter of Political and Civil rights. Pakistan is 
already a signatory of UN human rights charter and it should also sign this additional protocol.

The members of BSO were holding a protest in Karachi against the Balochistan operation in March 2005. Seven members were arrested between 24 to 25 March. Dr. Allah Nazar was one among seven members. He was subjected to inhuman torture, which resulted into loss of a memory and paralysis. Currently he is in central jail Quetta and is being tried in the terrorist courts. The constitution of Pakistan clearly lay down that "no one can be tortured under the condition to extract information". This is the only one example and number of other was present on the land of Balochistan. This is not the first time that Baloch faced the inhuman act but the access of these incidents is more than in past (HRCP, 2006).

\section{Internally Displaced Persons (IDPs)}

Insurgency of 2005 was centered in Bugti and Marri areas, which left almost $2,000,000$ people without a roof over their head. The military operation was followed by bombardment and firing over civil settlements, which forced people to leave their homes and to take refuge in different areas of Quetta, Sibi, Naseerabad and Bolan district. The UNICEF released its internal assessment of two months from July to August 2006. The report published that almost 26,000 women and 33,000 children displaced during insurgency (AITPN, 2007). Government of Pakistan rejected UNICEF figures and claimed that all IDPs had already returned their homes. The situation however, went from bad to worse by 2006 which alarmed the government and it allowed conditional permission to UN agency to visit affected areas. The UN agencies worked under the supervision of the local authorities and were not allowed to talk to press. Abdul Wahab Baloch head of Baloch Rights Council, a local NGO, confirmed that IDPs number was around 2,000,000 this was endorsed by the regional human right organization (Dedalus, 2007).

While the number of displaced persons (women and children) was so high, the living conditions in the refugee areas are unhealthy, with inadequate water supply, poor drainage system and insufficient food supply.

\section{Target Killing}

Latest trends of target killing started after the death of Bugti in 2006. The main targets of killers are Punjabis and non-Baloch. Three types of targets killing was observed in Balochistan, i.e., target killing of moderate political leaders, of non-Baloch settlers, and the sectarian based target killing. The target killing of political leader was on the base of spying for government authorities. Target killing in Khuzdar and Makran was observed on these grounds. Baloch Nationalist Movement (BNM) president Ghulam Muhammad Baloch and joint secretary Lala Munir along with Baloch Republican Party (BRP) secretary general killed in Turbat. Punjabi teachers were killed in Quetta, Mastung, Kalat, Hub and Khuzdar. There was an estimate that total 252 Punjabi settlers were killed in Balochistan up till the end of month of July 2010 alone. Target killing of Punjabi settlers in Balochistan forced the Punjabis to leave their houses and shift to some other province or locality. This situation leads to the scarcity of teachers in Balochistan. There is another view that land mafia were behind target killing so that residents would be forced to sell their property at lower price. 
The third type of killing is sectarian based. The target of this is Shia Hazara community and almost 200 people from this community have been killed by 2009 (Sial \& Basit, 2010).

Insurgents are killing Punjabis and settlers as a reaction of Nawab Akbar Bugti murder. Insurgents were targeting Punjabi on the grounds that Punjabi army killed Bugti. This situation has led to the brain drain of educated and working class of the province. This argument was furthered by Quetta University professor Kalimullah Berach. Teachers who belonged to different parts of Pakistan (Urdu-speaking and Punjabi) other than the province of Balochistan were murdered by insurgents. The target killing of teachers force them to leave the province as soon as possible to settle either to some safe place in Balochistan or to leave the province. Professor said that he also brought this issue to the notice of the government but nothing had been done so far. Ataullah Khan Mengal during his term as a Chief Minister of the province in 1972 issued an order to expel the Punjabi and Urdu-speaking "settlers" from the province including teachers from education sector. This decision caused unending damage to the educational sector of the province. The term "settler" started in his tenure. Total 33 teaching staff members including 16 with Doctorate degree left the University of Balochistan and got jobs in the other provinces. Balochistan Professor and Lecturer Association general-secretary Professor Khalil Khan said that almost 50 Punjabi and Urdu-speaking teacher left the province after the murder of Commerce College professor Amanat Ali and the Degree College Professor Ghulam Sarwar. The Balochistan Government School Teachers Association Chairman Dad Jan said it's not only Punjabi and Urdu-speaking teacher who want to be transferred from Baloch areas to Pashtun districts but Baloch teacher also wants to be transferred from the Baloch areas. These teachers were sacred of forceful disappearances and displacements by security agencies. Chief Secretary and the home department of the province said it is not that governments do not want to stop the target killing it's like we do not have resources to stop such activities. Chief Secretary Ahmed Bakhsh Lahri of Balochistan said that we have relaxed the rules of transfer for government servants so that they can move from the areas (Ahmed, 2010).

The geography of Balochistan distinguishes it from the rest of the provinces. Despite, the fact that the most land in Balochistan is dry, barren, uneven and therefore unsuitable for large scale agriculture, yet is blessed with abundant mineral resources, which if properly exploited, can turn Balochistan into a prosperous and self-sufficient province. However, the only hurdle is to tap those resources with the mutual consent of the local people. Balochistan province went through number of challenges covering infrastructure of health, education, agriculture, security and human rights violations. Province requires urgent attention of the provincial as well as federal government to address these grave issues. Musharraf regime did work towards increasing literacy rate in Balochistan. He increased education budget nationwide during his era. Statistic of Musharraf era shows an improved literacy ratio in Balochistan, in comparison with the past many years. However, low level of education and high illiteracy rates, especially in the areas like Dera-Bugti, \& Kohlu, is a major cause of unrest in Balochistan. Education brings up awareness of rights and duties of the citizens of a state. Education helps to improve the civic sense in the citizens in turn helps in better administration. Education not only hastens economic development but politically speaking, it helps people see as to who is using them to grind his own axe, and as to who their actual friends are. 


\section{References}

Ahmed, M. (2010, December).Targeting teachers Attack on senior teachers have hit higher education hard in Balochistan. Herlad, 42(12), 36-38.

AITPN. (2007). Balochistan: Jackboot justice in tribal heartland. http://www.aitpn.org/issues/11-01-07-Balochis.pdf

Baloch, S. (2007). The Balochistan conflict: Towards lasting peace. http:// spaces.brad.ac.uk: 8080/download/attachments 1745/Brief 7 Finalized 1.pdf.

Dedalus, S. (2007). The forgotten refugees of Balochistan. Middle East Research and Information Project, (244).40-41, 48.

Govt. of Balochistan. (2004). Literacy and education. Govt. of Balochistan

Human Right Commission. (2006). Human rights violation conflict in Balochistan. http://www.hrcp-web.org/pdf/conflict\%20in\%20balochistan--\%20 complete.pdf.

ICG. (2007). The forgotten conflict in Balochistan. www.crisisgroup.org.

Jetly, R. (2009). Resurgence of the Baluch movement in Pakistan: Emerging perspectives and challenges. In R. Jetly (Eds.), Pakistan in regional and global politics. London: Routledge.

Kundi, M. A. (1994). Balochistan A social cultural and political analysis. Quetta: Qasim Printers.

Muzaffar, M. Karamat, S. Saeed, K. (2018). Balochistan Insurgency: Causes and Prospects, Orient Research Journal of Social Sciences, Vol 3 Issue I, 112-128

PILDAT. (2012). Balochistan Civil-military relations. www.pildat.org.

Raman, B. (2004). Balochistan continues to haunt Musharraf. http://www.southasiaanalysis.org/papers13/paper1205html.

Rizvi, D. H.S. (2008). Socio economic-conditions of Balochistan during British period. In Riaz, A. (Eds.), Balochistan through history. Islamabad: Chair on Quaid-i-Azam and Freedom Movement Quaid-i-Azam University.

Salman, A. \& Raashid, M. (2008). Pro-poor resource allocation: Insights from people http://www.sappk.org/sites/default/files/publications/eng_publications/Pro_Poor_R eport_Insight_from_Peoples.Pdf.

Senate of Pakistan. (2005). Report of the parliamentary committee on Balochistan. http://www.senate.gov.pk/reports/mushahid17.pdf 
Sial, S \& Basit, A. (2010). Conflict and insecurity in Balochistan: Assessing strategic policy options for peace and security. Conflict and Peace Studies, 3 (4), 1-87.

Syed, J.H. (2008). Balochistan: The introduction of reforms and accession to Pakistan. Pakistan Journal of History and Culture, XXIX (2), 29-52.

Synnott, H. (2009). Transforming Pakistan ways out of instability. London: Routledge 